\title{
Endophytic Fungi Controls the Physicochemical Status of Maize Crop under Salt Stress
}

\author{
Raid Ali', Humaira Gul', Muhammad Hamayun ${ }^{1 *}$, Mamoona Rauf ${ }^{1}$, \\ Amjad Iqbal', Anwar Hussain', In-Jung Lee ${ }^{3}$ \\ ${ }^{1}$ Department of Botany, Abdul Wali Khan University Mardan, Pakistan \\ ${ }^{2}$ Department of Food Science \& Technology, Abdul Wali Khan University Mardan, Pakistan \\ ${ }^{3}$ School of Applied Biosciences, Kyungpook National University, Daegu 41566, Korea
}

Received: 4 January 2021

Accepted: 17 March 2021

\begin{abstract}
Salt stress is one of the abiotic stresses which negatively affects the growth and yield of different plants world-wide. The purpose of the present investigation was to analyze the physiological and biochemical parameters of maize plants exposed to salt stress with or without fungal association. The results indicated that salinity negatively affected the growth attributes, biochemical parameters and ionic status in maize. In contrast, WSQ association has improved the growth parameters, antioxidant enzyme activity, IAA and metabolites, N, P, Ca, K and Mg concentrations in maize. Moreover, WSQ association reduced lipid-peroxidation, $\mathrm{Na}, \mathrm{Cl}, \mathrm{Na} / \mathrm{K}$ and $\mathrm{Ca} / \mathrm{K}$ ratio in maize during salinity stress. The results of the present study concluded that the endophyticfungal strain WSQ can serve as a good strategic-tool to improve maize growth under salt-stress.
\end{abstract}

Keywords: endophytic fungi, proline, salinity, maize, endogenous hormones

\section{Introduction}

Salt stress and drought stress are very important abiotic stress factors that are becoming the main problem of agricultural lands. Salinity is in fact an important factor that determines the success rate of plant germination and seedling growth. Various physiological and biochemical characters of plants can be effected greatly due to abiotic stress factors, including salt stress [1-6]. Doménech-Carbó, et al. [7] explained salinity as a limiting-agent that is responsible for the plant species distribution in

*e-mail: hamayun@awkum.edu.pk salt-marshes and other salt contaminated habitats. In plant life cycle, germination of seed is an important phase that can determine the establishment of crop plants in the field. Presence of high salt concentration in the soil can deter seed germination process that can lead to low yields [8-11].

Zea mays (Maize) is considered as main and important crop worldwide. Within Pakistan, Zea mays ranked third after rice (Oryza sativa) and wheat (Triticumaestivum) crops, while KPK and Punjab provinces grow $98 \%$ of this crop. Maize crop cover 1.11 million hectaresof land in Pakistan that gives an average yield of 4.92 million-tons yearly [12]. This crop is the most widely-grown cereal crop in the world with great dietary importance [13]. Maize crop is rich in vitamins, such asvitamin C, K, E, B-complex [14]. 
Corn germ constituted of $35-56 \%$ oilthat can be extracted by improved wet-crushing process [15]. Also, maize plant has medicinal importance, for example vitamin B complex can be used for, skin, heart, brain and hair diseases, decoctions of different parts (e.g. leaf, root and silk) can be used for nausea, vomiting and bladder issues [14]. The nutritional and medicinal importance of this crop made it popular among the humans, but unfortunately the current climate change greatly effected the growth and production of this crop [8, 16]. However, losses in crop production and crop yield can be minimized by introducing resistant varieties or soil reclamation technologies.

In the world, all ecosystems comprised of microorganisms, which are important and versatile entities of that system. It has been studied that about $1 \%$ of different bacterial species and5\% of fungal specie are studied, while millions of microbial strains are still unknown and hidden in ecosystems [17]. Endophytes are one of the best examplesthat live in host plant tissues without causing any harm to the host cell [4, 5, 18]. Endophytic-fungi appeared to provide resistance to the host plant species under various stress different conditions [2, 16, 19, 20]. It is estimated that over 1-million of endophytic fungi has been discovered from the tissues of various plant species [21]. These fungal endophytes were noted to establish a symbiotic relationship with their host-plant, i.e. they can protect the host plant against environmental stress factors and in return fetch some of the nutrients from the host plants $[6,9,11]$. Keeping the beneficial role of the fungal endophytes in view, this study was designed to examine the role of endophytic fungal strain on growth, biochemical characters and ionic status of maize under normal as well as saline conditions.

\section{Materials and Methods}

\section{Collections and Purification of Endophytic Fungi}

Endophytic fungi WSQ was collected from the Plant Microbe Interaction Laboratory, Department of Botany, Abdul Wali Khan University Mardan. The strain was purified after repeated sub-culturing on potato dextrose agar (PDA) and incubated at $25^{\circ} \mathrm{C}$ for two weeks to produce a sufficient number of spores (conidia). The mycelia and spores formed on the PDA medium were scraped using a sterile No. 21 blade and placed in a $50 \mathrm{ml}$ sterile conical-tube. A $20 \mathrm{ml}$ sterile water was added in the conical-tube $(50 \mathrm{ml})$ and vortexed for $5 \mathrm{~min}$ for spore dispersion. The mixture (containing mycelia and spores) was then filtered with the help of Watman filter paper No. 2 to obtain a spore suspension. The final concentration of spores in solution was adjusted to $5 \times 10^{7}$ spores $/ \mathrm{ml}$ to be used in further experiments.

\section{Experimental Setup}

A pot experiment was conducted to determine the effect of $W S Q$ inoculation on maize growth. A completely randomized design was set up including the inoculation of maize with WSQ. Seeds of Zea mays, variety (Pre-Basic) were obtained from ARI (Agriculture Research Institute) Tarnab, Peshawar. Seeds were subjected to the viability test before starting the experiment. Uniform seeds were selected and dipped in $0.1 \%$ mercuric chloride for 60 seconds for sterilization. The mercuric chloride seeds were then washed thrice with distilled water to remove any traces of mercuric chloride. A total of 12 plastic pots ( $8.5 \mathrm{~cm}$ diameter and $12.5 \mathrm{~cm}$ deep) with a basal outlet for leaching purpose was arranged. The pots were filled with 300 grams of sandy loam soil (sand $=74.8 \%$, silt $=11.9 \%$, and clay $=13.2 \%$ ), having electrical conductivity $=0.9 \mathrm{dS} / \mathrm{m}$ and $\mathrm{pH}=7.2$. The sterilized seeds were sown in the pots and allowed to germinate at $23 \pm 2^{\circ} \mathrm{C}$. At seedling stage, a spore suspension of fungi @ $1 \mathrm{ml} / \mathrm{g}$ was applied as a treatment in the required set of pots. After 5-days of spore-suspension application, $\mathrm{NaCl}$ salt solution $(150 \mathrm{mM})$ was applied twice a week in all set of pots, except the controls (irrigated with tap water).

The experimental design had 4-sets of treatments, with three replications and each replicate consisted of five plants/pot.

Set I: Seedlings irrigated with $0 \mathrm{mM} \mathrm{NaCl}$.

Set II: Seedlings irrigated with $150 \mathrm{mM} \mathrm{NaCl}$.

Set III: Seedlings treated with fungal spores (WSQ) and irrigated with $0 \mathrm{mM} \mathrm{NaCl}$.

Set IV: Seedlings treated with fungal spores (WSQ) and irrigated with $150 \mathrm{mM} \mathrm{NaCl}$.

The experiment was proceeded up to 35 days and after the completion of the experiment, maize plants were harvested.

\section{Evaluation of Plant Growth Parameters}

Initially, the plants were cleaned with great care. After cleaning, the shoot and root lengths of the plants were measured with the help of ruler/scale. The number of plant leaves from each treatment was counted and then shoots and roots were separated. The weight of the separated shoots and roots were recorded by using an electrical balance. The shoots and roots were finally dried in an oven for $72 \mathrm{~h}$ at $60^{\circ} \mathrm{C}$ and recorded the weight after drying.

\section{Photosynthetic-Pigment Analysis}

Total-chlorophyll and carotenoid contents of freshleaf samples were estimated and calculated through a process as described by Maclachlan and Zalik [22]. Fresh leaf samples were ground in $3 \mathrm{ml}$ of acetone (80\%) using mortar and pestle. The mixture was transferred to the centrifuge tubes and centrifuged at $1000 \mathrm{rpm}$ for 
5 minutes. The supernatant was collected in the new tube and the pellet was washed again and centrifuged. The supernatant was pooled and adjusted the final volume to $7 \mathrm{ml}$ with acetone (80\%). The optical densities (OD) were recorded at $663 \mathrm{~nm}$ for chlorophyll-a, $645 \mathrm{~nm}$ chlorophyll-b, 480 and $510 \mathrm{~nm}$ for carotenoids using UV/VIS spectrophotometer (Perkin Elmer).

$$
\begin{aligned}
& \text { Chlorophyll a }(\mathrm{mg} / \mathrm{g})=\left(12.3 \mathrm{D}_{663}\right. \\
& \left.\quad-0.86 \mathrm{D}_{645} \mathrm{~d} * 1000 * \mathrm{w}\right) \times \mathrm{V} \\
& \text { Chlorophyll b }(\mathrm{mg} / \mathrm{g})=\left(12.3 \mathrm{D}_{645}\right. \\
& \left.-0.86 \mathrm{D}_{663} / \mathrm{d} * 1000 * \mathrm{w}\right) \times \mathrm{V} \\
& \text { Total Chlorophyll = Chla }+ \text { Chlb } \\
& \text { Carotenoids }(\mathrm{mg} / \mathrm{g})=\left(7.6 \mathrm{D}_{480}\right. \\
& \left.-1.49 \mathrm{D}_{510} / \mathrm{D} * 1000 * \mathrm{~W}\right) * \mathrm{~V}
\end{aligned}
$$

Estimation of Total Carbohydrate

Anthron method was adopted for the estimation of total-sugars in fresh leaf samples [23]. A $0.5 \mathrm{~g}$ of fresh leaf was crushed in $10 \mathrm{ml}$ of distilled water. After transferring the mixture in centrifuge tubes, a centrifugation was performed at $3000 \mathrm{rpm}$ for 5 mins. For the estimation of total carbohydrates, $0.1 \mathrm{ml}$ of the supernatant was mixed with $1 \mathrm{ml}$ phenol $(80 \%)$ and the mixture was incubated for 10 mins at room temperature. After incubation, $5 \mathrm{ml}$ of concentrated $\mathrm{H}_{2} \mathrm{SO}_{4}$ was added and the mixture was incubated on the bench for an hour. Glucose was used as a standard and the OD of the solution was measured at $485 \mathrm{~nm}$.

\section{Estimation of Total Proteins}

Total proteins of mungbean plants were measured through well-defined method of Bradford [24]. A $0.1 \mathrm{~g}$ leaf sample was homogenized in ice-cold pestle and mortar using a $5 \mathrm{ml}$ of phosphate buffer ( $\mathrm{pH}=7,0.1 \mathrm{M}$ potassium phosphate). The mixture was centrifuged at $12,000 \mathrm{rpm}$ for $20 \mathrm{mins}$. To $0.2 \mathrm{ml}$ of the supernatant, $4.8 \mathrm{ml}$ of phosphate buffer was added. For the estimation of total proteins, $0.1 \mathrm{ml}$ of the diluted extract was taken in a clean test tube and added $5 \mathrm{ml}$ Bradford reagent. Bovine serum albumin was used as a standard and the OD was then recorded at $595 \mathrm{~nm}$.

\section{Estimation of Total Lipids}

Total lipid contents were measured according to the well-established method of Van Handel [25]. Approximately, $0.2 \mathrm{~g}$ of leaf sample was ground in chloroform:methanol $(2: 1 \mathrm{v} / \mathrm{v})$ and the mixture were transferred to the tubes. The contents of each tube were shaken vigorously, added $0.8 \mathrm{ml}$ of $0.73 \% \mathrm{NaCl}$ and let it stand on the bench top at room temperature. After the appearance of three layers, the lower layer containing lipids were separated/collected through the separatory funnel. After separation of lipid layer, added $0.1 \mathrm{ml}$ of sulfuric acid and the mixture was shaken and then heated at $100^{\circ} \mathrm{C}$ for 10 minutes. Cooled the sample and added $2.4 \mathrm{ml}$ of vanalin reagent. Pure canola oil was used as a standard and the absorbance was recorded at $490 \mathrm{~nm}$ upon the appearance of pink colour.

\section{Estimation of Total Proline}

Bates, et al. [26] method for the extraction and estimation of proline in plants were adopted. Leaf sample $(0.5 \mathrm{~g})$ was ground in $10-\mathrm{ml}$ sulphosalicyclic acid $(3 \%)$ and the mixture was centrifuged for 5 mins at $3000 \mathrm{rpm}$. To $2-\mathrm{ml}$ of the collected supernatant in a glass tube, added $2 \mathrm{ml}$ each of the glacial aceticacid and freshly prepared ninhydrin reagent and the mixture was heated at $100^{\circ} \mathrm{C}$ for an hour. The contents of the tube were cooled, added $4 \mathrm{ml}$ of the toluene to it and the mixture was vortexed vigorously. Pure proline from Sjima Aldrich was used as a standard and the OD was recorded at $520 \mathrm{~nm}$.

\section{Estimation of Total Phenolics}

A $0.5 \mathrm{~g}$ of leaf sample was ground in $80 \%$ ethanol $(5 \mathrm{ml})$ and the mixture was filtered through Watmann filter paper No.1. The filterate was evaporated to dryness and transferred to a $10 \mathrm{ml}$ glass-tube. To the dried filterate, added $3 \mathrm{ml}$ of distilled water and the contents of the tube were vortexed. A $0.5 \mathrm{ml}$ of Folinciocalteau reagent and $2 \mathrm{ml}$ of $\mathrm{Na}_{2} \mathrm{CO}_{3}$ was added to the the solution and mixed. After the appearance of the blue colour the contents were heated for $1 \mathrm{~min}$ and then allowed to cool. The absorbance of the solution was finally measured at $650 \mathrm{~nm}$. Catechol was used as a standard.

\section{Total Flavonoids Measurements}

Total flavonoids were measured by the method as described by El Far and Taie [27]. Approximately, $5 \mathrm{~g}$ of the leaf sample was macerated in $80 \%$ ethanol $(50 \mathrm{ml})$ for the preparation of extract. After 1 day of incubation at room temperature, the extract was centrifuged for $15 \mathrm{mins}$ at $10,000 \mathrm{rpm}$. To $250 \mu \mathrm{l}$ of the extract supernatant, added $1.25-\mathrm{ml}$ distilled water, $7 \mu \mathrm{l}$ of $\mathrm{NaNO}_{2}(5 \%)$ and the mixture was incubated for $5 \mathrm{~min}$ at room tempertaure. After incubation, added $150 \mu \mathrm{l}$ of $\mathrm{AlCl}_{3} \cdot \mathrm{H}_{2} \mathrm{O}(10 \%)$ and the mixture was again incubated for 6 minutes. After incubation, added $500 \mu \mathrm{l}$ of $1 \mathrm{M}-\mathrm{NaOH}$ and $275 \mu \mathrm{l}$ distilled water to the mixture and OD was recorded at $415 \mathrm{~nm}$. Quercetin was used as a standard.

\section{Determination of Lipid Peroxidation}

Heath and Packer [28] method was adopted for the determination of lipid peroxidation. Approximately, 
$0.1 \mathrm{~g}$ plant material was macerated in $2.5-\mathrm{ml}$ of $0.1 \%$ tricholoro acetic-acid. The mixture was then transferred to centrifuge tubes and centrifuged for $20 \mathrm{~min}$ at $3000 \mathrm{rpm}$. The collected supernatant $(1 \mathrm{ml})$ was mixed with $2.25 \mathrm{ml}$ of $0.5 \%$ thiobarbituric-acid and $20 \%$ tricholoro acetic-acid. The mixture was heated at $95^{\circ} \mathrm{C}$ for $30 \mathrm{~min}$, cooled in ice bath, and then centrifuged for 10 minutes at $3000 \mathrm{rpm}$. The OD of the collected supernatant was recorded at $532 \mathrm{~nm}$ and $600 \mathrm{~nm}$. Malondialdehyde was used as a standard.

\section{Determination of Catalase Activity}

Catalase enzyme activity in fresh leaves was measured through protocol described by Chandlee and Scandalios [29]. Approximately, $1 \mathrm{~g}$ of leaf sample was homoginized in $2.6 \mathrm{ml}$ of $0.1 \mathrm{M}$ sodium phosphate buffer $(\mathrm{pH}=6.5)$ using pre-cooled mortar and pestle. A reaction-mixture was made by mixing $0.1 \mathrm{ml}$ of enzyme-extract with $1 \mathrm{ml}$ of potassium phosphate buffer (100 mM, pH-7.0) and $0.4 \mathrm{ml} \mathrm{H}_{2} \mathrm{O}_{2}$ (200 mM). Reduction in absorbance due to decomposition of $\mathrm{H}_{2} \mathrm{O}_{2}$ was measured at 30 seconds intervals and $240 \mathrm{~nm}$.

\section{Determination of Ascorbate Peroxidases Activity}

Asada [30] method with little modification was used for the measurement of the ascorbate peroxidase activity in fresh mung bean leaves. Approximately, $1 \mathrm{~g}$ of the leaf sample was ground in $3 \mathrm{ml}$ of extraction mixture containing phosphate buffer ( $\mathrm{pH} 7.0), 10 \mathrm{mMKCl}$, $1 \mathrm{mM} \mathrm{MgCl}$, and $10 \mathrm{mM}$ EDTA. The ground mixture was centrifuged at $10,000 \mathrm{~g}$ for $20 \mathrm{~min}$ at $4^{\circ} \mathrm{C}$ and the supernatant was collected as enzyme extract. The enzyme extract $(0.1 \mathrm{ml})$ was mixed with the reaction mixture $(0.9 \mathrm{ml})$, composed of ascorbic-acid $(0.2 \mathrm{mM})$ + potassium phosphate buffer $(50 \mathrm{mM}, \mathrm{pH}-7)+$ EDTA $(0.2 \mathrm{mM})+\mathrm{H}_{2} \mathrm{O}_{2}(20 \mathrm{mM})$. Reduction in optical density was measured at $290 \mathrm{~nm}$ and 30 seconds interval.

\section{Evaluation of Endogenous IAA}

IAA was quantified using Salkowski reagent. Salkowski reagent was made by using the technique of Benizri, et al. [31]. To prepare Salkowski reagent, $1 \mathrm{ml}$ of solution $\mathrm{A}\left(0.5 \mathrm{M} \mathrm{FeCl}_{3}\right)$ was mixed with $50 \mathrm{ml}$ of solution $\mathrm{B}\left(35 \% \mathrm{HClO}_{4}\right)$. Plant material $(0.5 \mathrm{~g})$ was crushed by mortar and pestle in $5 \mathrm{ml}$ distilled water and centrifuged at $10000 \mathrm{rpm}$ for $15 \mathrm{~min}$. The supernatant $(1 \mathrm{ml})$ was mixed with $2 \mathrm{~m} 1$ of Salkowski reagent in a test tube. The contents of the tube were incubated for $30 \mathrm{~min}$ in the dark at room temperature. Salkowski reagent $(4 \mathrm{ml})$ was used as a control. OD was taken at $540 \mathrm{~nm}$ using UV/VIZ spectrophotometer.

\section{Analysis of Minerals}

Leaves sample $(0.25 \mathrm{~g})$, previously dried in an oven was taken in a $50 \mathrm{ml}$ flask. A $6.5 \mathrm{ml}$ of acid solution consisting of nitric acid, sulphuric acid, perchloric acid (5:1:0.1) was added to it. The mixture was digested in a fume hood on a hot plate. Appearance of white fumes indicated the complete digestion of the sample. After the digestion, the contents of the digestion flask were allowed to cool. The cooled digest was collected in $50 \mathrm{ml}$ volumetric flasks and the volume was set to $50 \mathrm{ml}$ with distilled water. The extract was passed through the Whatmann filter paper before quantifying the mineral elements by Atomic Absorption Spectrophotometer (Shimadzu AA-670).

\section{Statistical Analysis}

A completely randomized design was set up consisting of 4-sets of treatments, with three replications and each replicate consisted of five plants/pot. ANOVA (analysis of variance) was used for the analysis of data and means were compared by a Duncan multiple range test at $\mathrm{p}<0.05$, using SPSS for windows 21.0 (SPSS Inc., Chicago, IL, USA). Graphs were constructed by using Graphpad Prism 6.0.

\section{Results and Discussion}

\section{Effect of WSQ Association on the Establishment of Salt Stressed Maize}

Application of salt can cause substantial restrictions on plant growth and development.

Significant alterations in different plant growth parameters upon exposure to abiotic stress condition can define the impact of that stress on plant species. In the present study, we have evaluated salt stress on maize species. Exposure of maize plants to salt stress caused significant reduction in plant growth parameters, which reflected in terms of shoot and root lengths, number of leaves, and shoot and root weights (Fig. 1a,b). However, maize plants associated with WSQ when exposed to normal or saline conditions, exhibited root and shoot growth promotion. Similarly, Bacillus subtilis improved the root- and shoot-growth of Acacia gerrardi under salt stress [32]. Kang also observed the beneficial effect of various endophytes on plant species during stress and stated that the endophytes are getting strong recognition around the globe [33]. In fact, endophytes (bacteria/fungi) might play an important role in maintaining plant's fitness and normal-health in severe environmental-conditions.

In the present project, considerable decrease was observed in a leave-number of maize plants, which was significantly influenced by different levels of $\mathrm{NaCl}$ salt (Fig. 1c). Nusrat, et al. [11] and Raid, et al. [3] also observed the same phenomenon caused by salt-stress in maize and mungbean plants. In different stressconditions (drought and salinity) plant species exhibited reduction in leaf area and leaf number, which is due to low turgor pressure leading to reduced leaf size and 
increase in leaf senescence [3]. After absorption of salts through plant roots, the salts can accumulate inside the cells, which may cause reduction in total-photosynthetic leaf-area due to low carbon supply [34]. On the other hand, association of WSQ with maize plants improved the number of leaves under the salt stress. Similar observations have been recorded by Raid, et al. [3] in endophyte associated mung bean plants exposed to salt stress.

Application of salt can cause adverse effects on a dry weightof plant species. The current project explored the fact that dry-weight of maize drastically decreased with $\mathrm{NaCl}$ treatment (Fig. 1(d-f)). Reduction in dry-matter yield under high salt stress might be linked with the reduced hydrolysis of reserved-food and its translocation to growing-shoot. Muhammad, et al. [10] also observed a reduction in different growth parameters (e.g. shoot's dry-weight, root's dry-weight) after exposing the plant to salt-stress. However, an improvement in biomass production of maize plants under normal and salt stress was noticed, when plants get associated with the fungal endophyte WSQ (Fig. 1d-f). Muhammad, et al. [10] in their experiments observed an increase in fresh-biomass and dry-biomass, chlorophyll-content, bud-number and flower-number in endophyte associated plants as compared to the nonassociated plants.

\section{Effect of WSQ on the Photosynthetic Activity of the Salt Stressed Maize}

A significant reduction in photosynthetic pigments (chl-a, chl-b, total-chlorophyll) were noticed in maize plants undergoing high salinity stress $(150 \mathrm{mMNaCl})$, whereas chl-a/b ratio and carotenoid contents were increased as compared to the control plants (Fig. 2). Sehrawat, et al. [35] also noticed significant necrosis and chlorosis in plant leaves under salinity stress. Moreover, they noted reduction in leaf colour, leaf area, plant height, leaf number, number of clovers, which they linked to the reduction in chlorophyll and carotenoid contents in experimental plants exposed to
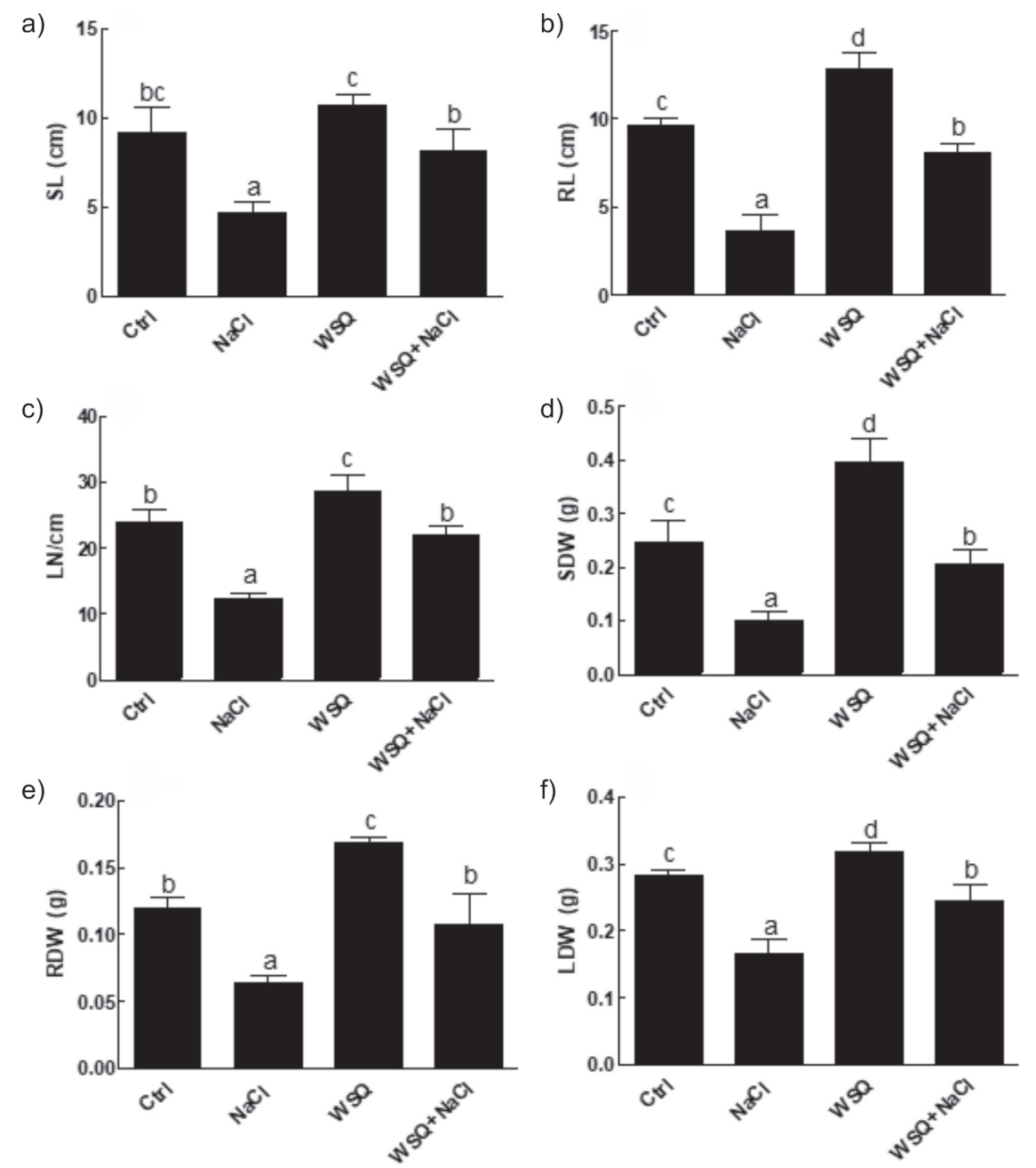

Fig. 1. Effect of $\mathrm{NaCl}$ on maize growth parameters with or without WSQ association. a) shoot length (SL); b) root length (RL); c) leaf number (LN); d) shoot dry weight (SDW); e) root dry weight (RDW); f) leaf dry weight (LDW); ctrl = control (without Nacl stress and WSQ inoculation). Each bar represents the mean of triplicated data with \pm SE. Bars that are labeled with different letters are significantly different from one another at $\mathrm{p}<0.05$. 
salt stress. Reduced photosynthetic-pigments (e.g. chl-a, chl-b, total chl and carotenoids) in plants under drought and salt stresses might lead to low net photosynthetic rate [36]. In plant salt-stress can cause declination in chl-contents, which might be due to the inhibition in pigment-biosynthesis and accelerated pigmentdegradation. Though, chl-a andchl-b both reduced under osmotic-stress, but chl-a/chl-b ratio increased during salt stress. Certainly, a slow reduction in chl-a as compared to the chl-b under stress conditions might be because of the conversion of chl-b into chl-a during the degradation process. During the present investigation, the association of fungal endophytehas rescued the maize plants under salt stress. A significant improvement in chl-a, chl-b, total-chl, a/b ratio and carotenoid contents were noticed in WSQ associated maize as compared to the non-associated maize exposed to the salt stress (Fig. 2). Azad and Kaminskyj [37] also noticed an increase in plant growth and total biomass of the endphyte associated experimental plants as compared to the host plant subjected to the salt stress. An increase in cholorophyll contents, root and shoot lengths, root and shoot weight and total biomass was observed in A. japonicus associated soybean and sunflower under abiotic stress [38]. The enhancement in chlorophyll contents of the endophyte associated plants can be linked with the improved photosynthetic-rate.

\section{Effect of WSQ on Sugars, Protein and Lipid Contents of the Salt Stressed Maize}

Under abiotic stress conditions, metabolic activities of the host plants can be disturbed with the alterations in total carbohydrates of plant species. The results of this study revealed a significant decrease in the total carbohydrates in maize after treatment with salt (Fig. 3a). Ouhaddach, et al. [39] observed significant changes in the total carbohydrate contents of the experimental plants under stress, however, changes were more pronounce in leaves than in roots. Moreover, the


Fig. 2. Effect of $\mathrm{NaCl}$ stress on chlorophyll and carotenoid contents of maize seedlings with or without WSQ association. a) chlorophyll a (Chla) contents in maize on a fresh weight (FW) basis; b) chlorophyll b (Chlb) contents in maize on a fresh weight (FW) basis; c) ratio of chlorophyll a to chlorophyll (Chla/Chlb); d) total chlorophyll (T.Chl) contents in maize on a fresh weight (FW) basis; e) carotenoid (Crtd) contents in maize on a fresh weight (FW) basis; ctrl = control (without Nacl stress and WSQ inoculation). Each bar represents the mean of triplicated data with $\pm \mathrm{SE}$. Bars that are labeled with different letters are significantly different from one another at $\mathrm{p}<0.05$. 
effect of salt-stress on total carbohydrates accumulation was observed more in source leaves as compare to sink leaves [40]. Furthermore, the association of WSQ with maize plants caused a significant increase in plant's total carbohydrate contents under normal and saline conditions (Fig. 3a). Bagheri, et al. [41] confirmed a significant increase in total sugar contents of the rice plant after exposure to $\mathrm{NaCl}$ stress. Aspergillus violaceofuscus and Aspergillus niger associated soybean plants subjected to abiotic stress were observed to accumulate high concentration of total sugars in seedlings $[20,42]$.

Under saline conditions, accumulation of different proteins occurs in cytoplasm that causes changes in the cell's cytoplasmic-viscosity, which in turn play a major role in osmotic-adjustment of the cell. In the present study, treatment of maize plants with different concentrations of $\mathrm{NaCl}$ exhibited increase in protein content. However, association of WSQ with maizecontrolled the level of protein contents in host plants under normal and saline conditions (Fig. 3b). Inoculation of rice plants with Gliocladiumcibotii under salt stress showed an increase in RWC, total antioxidant enzymes, total proteins, proline, root and shoot biomass [2]. Similarly, Trichodermaressei was held responsible for the host plant growth promotion and improvement in the primary metabolite concentrations under saltstress. In fact, T. ressei improved the biomass of aerialparts and roots, primary metabolites concentration, electrolyte leakage (EL), free-proline and antioxidant activity of wheat plants as compare to the control under salt stress.
Environmental stress factors can deteriorate the lipid contents of the plants due to the disordered cohesion of membrane proteins and lipid. Results of the present investigation revealed a significant promotion in lipid contents of the maize plants under salt stress (Fig. 3c). On the other hand, application of WSQ improved the total-lipid contents of the salt stressed maize plants. Ismail, et al. [38] reported an increase in total lipids of $A$. japonicas associated soybean and sunflower under abiotic stress.

\section{Effect of WSQ on Phenolic Contents of the Salt Stressed Maize}

Phenolic compounds are prevalent secondary metabolites in plants that play important role in plant defense during various stress conditions. Phenolics provide protection against the generated ROS during biotic and abiotic stresses. The results of the present project exhibited an increased production of phenolics in maize plants subjected to the salt-stress (Fig. 4a). On the contrary, the inoculation of fungal endophyte WSQ has controlled the production of phenolic contents in the maize plant under stress. According to Singh [43] the accumulation of high phenolic contents in plant tissues during salt stress have a protective role, i.e. they can prevent cell membrane damages. Moreover, phenolics has the ability to scavenge the reative oxygen species generated during stress conditions. Khushdil, et al. [9] observed increased phenolic-content in pearl millet plants exposed to severe salt stress, but the stress level was very low in plants that were inoculated with
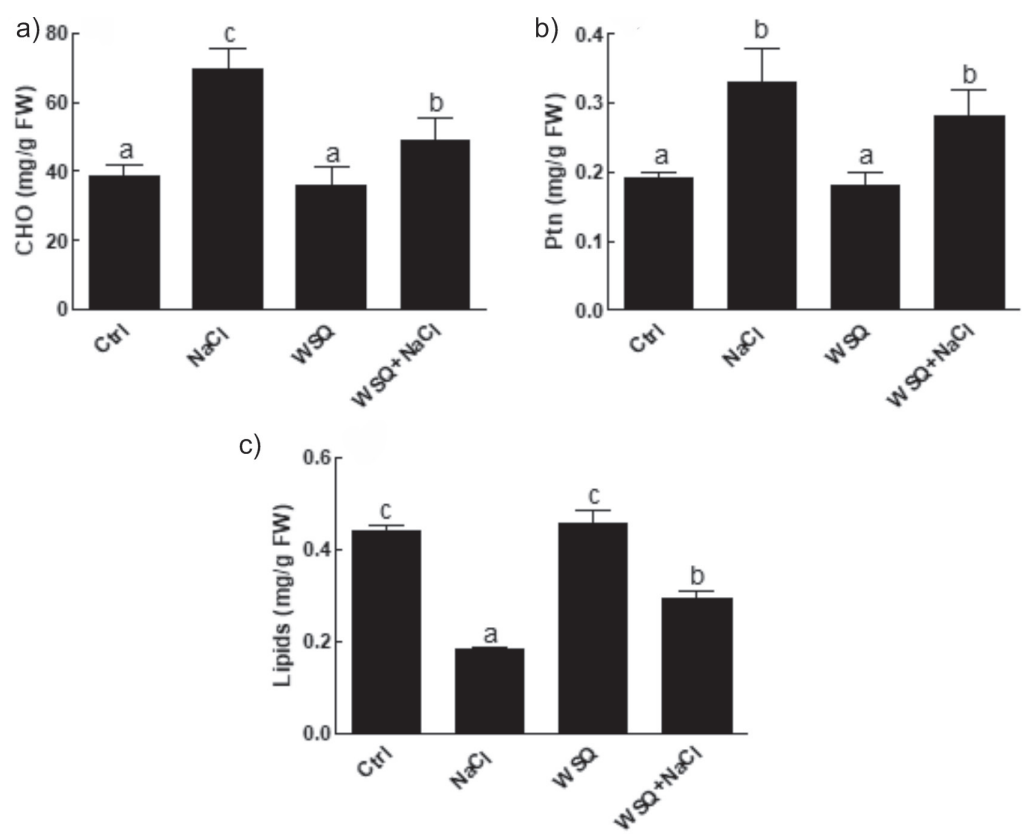

Fig. 3. Effect of $\mathrm{NaCl}$ stress on primary metabolites of maize seedlings with or without WSQ association. a) carbohydrate (CHO) contents in maize on a fresh weight (FW) basis; b) protein (ptn) contents in maize on a fresh weight (FW) basis; c) lipid contents in maize on a fresh weight $(\mathrm{FW})$ basis; $\mathrm{ctrl}=$ control (without Nacl stress and WSQ inoculation). Each bar represents the mean of triplicated data with \pm SE. Bars that are labeled with different letters are significantly different from one another at $\mathrm{p}<0.05$. 
endophyte. Our results are in agreement of Khushdil, et al. [9], where the WSQ association exhibited improvement in phenolic contents of the maize plants under salt stress (Fig. 4a). The association of B. subtilis with chickpea plants under salt-stress exhibited high amount of phenolics and proline [44]. These results shows that endophytes plays a handy role in activating the defensive mechanism of the host plants to tolerate stress.

\section{Effect of WSQ on Proline Accumulation in the Salt Stressed Maize}

Proline is enlisted as stress marker and compatible organic-solute having low molecular weight. Proline has vital role in cell signaling, stress protection, energy production and it can serve as a hydroxyl radical scavenger [45, 46]. In the present study, application of salt cause accumulation of high proline contents in maize plants as compared to the control plants. Association of endophytic WSQ with maize on the other hand showed significant improvement in proline contents (Fig. 4b). Similarly, Azotobacter chrocoocum (A101) as a plant growth promoting rhizobacteria (PGPR) controlled proline contents, water uptake, photosynthetic efficiency and water use efficiency in the basil plants subjected to stress [47]. Proline accumulation in plants can be normalized through down or up-regulation of the enzyme that are responsible for the degradation or biosynthesis of proline [48]. So it might be possible that plant-microbe interation regulates the proline production by controlling the expression of proline metabolizing enzymes.

\section{Effect of WSQ on Tannin Contents of the Salt Stressed Maize}

The results of the total tannins revealed a considerable increase in maize plants under saline condtions. The production of tannins was controlled when the salt stressed maize plants were inoculated with the endophyte WSQ (Fig. 4c). Zohra, et al. [49] also reported higher amounts of tannin in roots and leaves of Mentha suaveolens after the induction of salt stress.

\section{Effect of WSQ on Flavonoid Contents of the Salt Stressed Maize}

Flavonoids, especially the iso-flavonoids play major role in defense mechanism of plants under stress conditions $[6,19]$. The present results revealed that saltstress caused an increase in flavonoid contents of maize plants. However, maize plants associated with WSQ have improved levels of the flavonoid contents (Fig. 4d). This means that the endophyte WSQ has rescued the maize plants exposed to high salt stress by regulating the production of flavonoids. Quite recently different researchers have observed similar phenomenon in different plant species associated with enophytes and
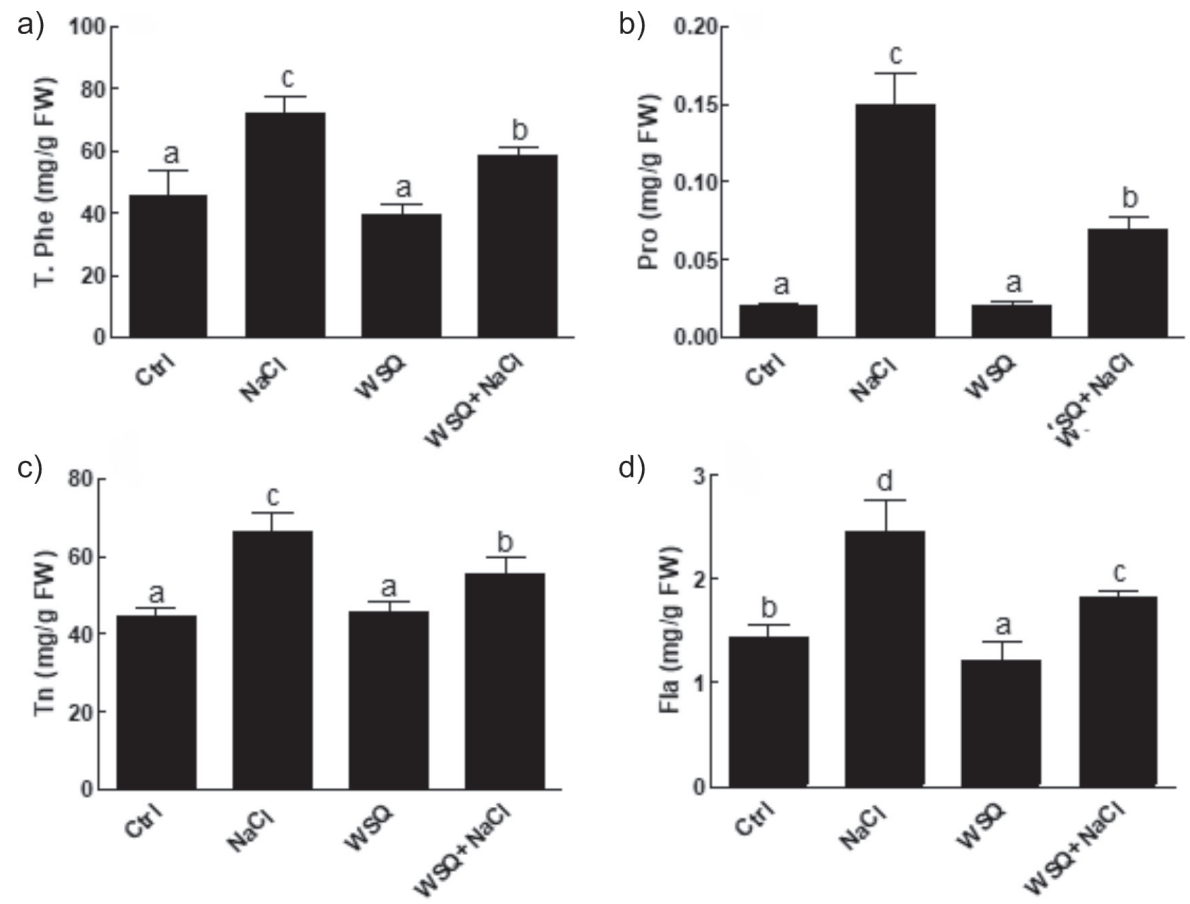

d)

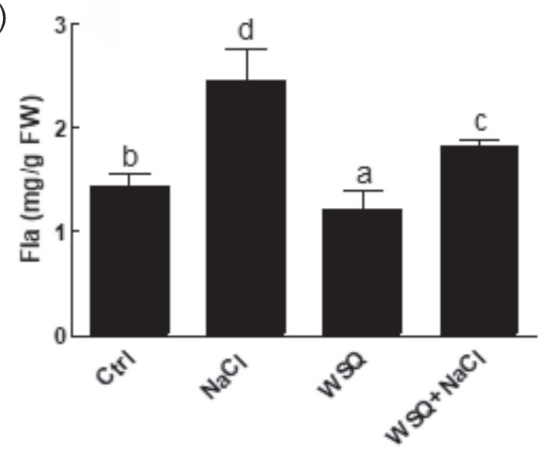

Fig. 4. Effect of $\mathrm{NaCl}$ on secondary metabolites of maize seedlings with or without WSQ association. a) total phenolics (T.Phe) contents in maize on a fresh weight (FW) basis; b) proline (Pro) contents in maize on a fresh weight (FW) basis; c) tannin (Tn) contents in maize on a fresh weight (FW) basis; Figure d) Flavonoids (Fla) contents in maize leaves on a fresh weight (FW) basis; ctrl = control (without Nacl stress and WSQ inoculation). Each bar represents the mean of triplicated data with \pm SE. Bars that are labeled with different letters are significantly different from one another at $\mathrm{p}<0.05$. 
exposed to high salt stress [11, 18]. Ismail, et al. [38] studied A. japonicas associated sunflower and soybean and observed an increased amount of flavonoids in endophyte treated seedlings in comparison to the A. japonicus-frees eedlings. The endophytic association in sunflower and soybean plants ameliorated the stress and promoted the plant growth under stress conditions. The results of the study by Yang, et al. [50] also confirmed the present findings, where they observed higher production of flavonoids in salt stressed plants inoculated with endophytes.

\section{Effect of WSQ on Membrane Lipid Peroxidation the Salt Stressed Maize}

Lipid peroxidation (LP) is defined as a nonenzymatic auto-oxidative process due to reactive oxygen species (ROS) of plants and this parameter used as an indicator to assess any plant's sensitivity to salt-induced oxidativestress state [51]. The results of the present study revealed a significant increase in the MDA value of the maize plants exposed to high saline conditions. Though salt stress have a very negative effect on maize plants, but inoculation of the plants with WSQ has a positive effect on lipid peroxidation (Fig. 5a). In fact, the association of endophytic WSQ was more effective in normalizing the lipid peroxidation of the stressed maize plants. An increased lipid peroxidation under stressful conditions was also observed in halophytic plant species, Cakile maritimum [52]. Moreover, Aspergillus terreus caused significant reduction in the lipid peroxidation of pearl millet plants at all tested $\mathrm{NaCl}$-concentrations [9]. This phenomenon might occur as a result of initial activity of antioxidant-enzymes to scavenge the ROS and then reacts with membrane-lipids, thus leading to the reduction in lipid-peroxidation.

\section{Effect of WSQ on Catalase and Ascorbate Peroxidase Activity of the Salt Stressed Maize}

Among anti-oxidant enzymes, catalase is a most effective enzyme for prevention of oxidative-damage in the plant body that decomposes $\mathrm{H}_{2} \mathrm{O}_{2}$ to $\mathrm{H}_{2} \mathrm{O}$ and $\mathrm{O}_{2}$ [53]. During present investigation, an increase in catalase activity was observed in maize plant after the application of salt. On the contrary, an association of endophytic fungal strain (WSQ) caused a significant change in catalase activity under normal and saline environment (Fig. 5b). Raid, et al. [3] and [10] explained ionic-stress or salt-stress can cause significant variations in the activity of catalase enzyme in tested plant species, which might be due to the production of $\mathrm{H}_{2} \mathrm{O}_{2}$.

During osmotic stress ascorbate peroxidase (APX) enzyme neutralize the ROS and provide protection to plants [54]. In the present project, we found an increased activity of ascorbate peroxidase in salt stressed maize plants. Contrary to that a significant change in the activity of APX enzyme was noticed in the WSQ associated maize plants exposed to salinity stress (Fig. 5c). Enhanced activity of APX was noted


Fig. 5. Effect of $\mathrm{NaCl}$ on stress enzymes of maize seedlings with or without WSQ association. a) lipid peroxide (LPO) in maize on a fresh weight (FW) basis; b) catalase (CAT) activity in maize on a fresh weight (FW) basis; c) ascorbate peroxidase (APO) contents in maize on a fresh weight (FW) basis; ctrl = control (without Nacl stress and WSQ inoculation)Each bar represents the mean of triplicated data with \pm SE. Bars that are labeled with different letters are significantly different from one another at $\mathrm{p}<0.05$. 




Fig. 6. Effect of $\mathrm{NaCl}$ stress on indole acetic acid (IAA) of maize seedlings with or without WSQ association. Each bar represents the mean of triplicated data with \pm SE. Bars that are labeled with different letters are significantly different from one another at $\mathrm{p}<0.05$.

in Brassica juncea after exposure to salt stress [55]. Higher production of APX in B. juncea was linked to the over-expression of the APX gene that provided the protectve mechanism against oxidative-stress [55]. Furthermore, Ismail, et al. [38] and Ismail, et al. [36] found that Aspergillus japonicas and Aspergillus flavus improved the APX activity in soybean and sunflower under stress environment. Bagheri, et al. [41] worked on Piriformospora indica associated rice plant exposed to $\mathrm{NaCl}$ stress. They observed an increased activity of CAT and APX in P. indica associated rice plants as compared to $P$. indica free plants. So, it is possible that higher activity of antioxidant enzymes can help the plants to reduce excessive production of ROS and minimize the chance of oxidative burst.

\section{Effect of WSQ on Endogenous Indole Acetic Acid (IAA) Accumulation of the Salt Stressed Maize}

The results of the present study revealed a considerable reduction in maize plants endogenous
IAA levels in the presence of high salt. Neverthless, a significant change in IAA concentration was observed in the WSQ inoculated maize plants under normal and salt stress (Fig. 6a). Bilal, et al. [56] observed improved GA and IAA level in endophyte associated Oxalis corniculata exposed to $\mathrm{NaCl}$ stress. A. japonicas association with plants (sunflower and soybean) caused growth improvement due to high IAA production under stress conditions [38].

\section{Effect of WSQ on Mineral Contents of the Salt Stressed Maize}

The results of the present study exhibited an increase in the sodium and chloride ions concentration of the maize plants subjected to salt stress. Whereas, the sodium and chloride ions concentration of the maize plants associated with endophytic fungus (WSQ) was significantly low as compared to the WSQ free maize plants (Table 1). Rahneshan, et al. [57] also observed an increased accumulation of metal ions in stem, root and leaves of the tested crops grown under saline conditions. However, increased accumulation of metal ions during salt stress can be handled up to some extent after inoculation the plants with endophytes. Ceratainly, the endophytes might help the host root to restrict the uptake of the metal ions followed by its accumulation in host plant tissues [3]. So, the negative effects of this stress factor could be handled up to some extent through the use and association of potent endophytes. The current study also revealed reduced calcium, potassium and magnesium ions in maize plants when grown under saline conditions. Association of maize with endophytic fungi (WSQ) cause enhancement in potassium and magnesium levels even under high salt stress conditions (Table 1). Abd-Allah, et al. [58] evaluated different physic-chemical characteristics of bean plant under salt stress. After inoculating the bean plants with arbuscular mycorrhizal fungi (AMF), they observed improvement in plant health. Besides, AMF helped the bean plants to maintain ion balance, reduced potassium deficiency and reduced $\mathrm{Na} / \mathrm{K}$

Table 1. Mineral profile of WSQ-associated and non-associated maize seedlings under normal and salt stress conditions.

\begin{tabular}{|c|c|c|c|c|c|c|c|c|c|}
\hline \multirow{2}{*}{ Treatments } & \multicolumn{9}{|c|}{ Ionic Status (mg/g DW) } \\
\hline & $\mathrm{Na}$ & K & $\mathrm{Ca}$ & $\mathrm{Mg}$ & $\mathrm{N}$ & $P$ & $\mathrm{Cl}$ & $\mathrm{Na} / \mathrm{K}$ & $\mathrm{Na} / \mathrm{Ca}$ \\
\hline Ctrl & $\begin{array}{c}4.15 \\
\pm 0.5 \mathbf{b}\end{array}$ & $\begin{array}{c}33.1 \\
\pm 0.4 \mathbf{b}\end{array}$ & $\begin{array}{c}17.3 \\
\pm 2.0 \mathbf{b}\end{array}$ & $\begin{array}{c}15.8 \\
\pm 0.4 \mathbf{b}\end{array}$ & $\begin{array}{c}50.5 \\
\pm 1.6 \mathrm{c}\end{array}$ & $\begin{array}{c}18.3 \\
\pm 1.2 \mathrm{c}\end{array}$ & $\begin{array}{c}4.7 \\
\pm 0.5 \mathbf{b}\end{array}$ & 0.13 & 0.24 \\
\hline $\mathrm{NaCl}$ & $\begin{array}{c}70.8 \\
\pm 1.7 \mathbf{d}\end{array}$ & $\begin{array}{c}24.9 \\
\pm 2.8 \mathbf{a}\end{array}$ & $\begin{array}{c}12.8 \\
\pm 1.7 \mathbf{a}\end{array}$ & $\begin{array}{c}11.4 \\
\pm 1.2 \mathrm{a}\end{array}$ & $\begin{array}{c}26.4 \\
\pm 1.0 \mathrm{a}\end{array}$ & $\begin{array}{c}8.9 \\
\pm 1.8 \mathbf{a}\end{array}$ & $\begin{array}{c}56.0 \\
\pm 6.2 \mathrm{~d}\end{array}$ & 2.80 & 5.5 \\
\hline WSQ & $\begin{array}{c}2.95 \\
\pm 0.2 \mathbf{a}\end{array}$ & $\begin{array}{c}44.5 \\
\pm 0.2 \mathrm{c}\end{array}$ & $\begin{array}{c}20.9 \\
\pm 1.8 \mathbf{c}\end{array}$ & $\begin{array}{c}21.0 \\
\pm 1.1 \mathrm{~d}\end{array}$ & $\begin{array}{c}61.5 \\
\pm 1.9 \mathrm{~d}\end{array}$ & $\begin{array}{c}19.6 \\
\pm 2.5 \mathrm{c}\end{array}$ & $\begin{array}{c}2.5 \\
\pm 0.2 \mathbf{a}\end{array}$ & 0.07 & 0.14 \\
\hline $\mathrm{WSQ}+\mathrm{NaCl}$ & $\begin{array}{c}21.1 \\
\pm 0.7 \mathbf{c}\end{array}$ & $\begin{array}{c}32.7 \\
\pm 1.0 \mathbf{b}\end{array}$ & $\begin{array}{c}15.5 \\
\pm 1.2 \mathbf{b}\end{array}$ & $\begin{array}{c}19.7 \\
\pm 0.9 \mathbf{c}\end{array}$ & $\begin{array}{c}42.7 \\
\pm 1.2 \mathbf{b}\end{array}$ & $\begin{array}{c}14.7 \\
\pm 1.7 \mathbf{b}\end{array}$ & $\begin{array}{c}31.4 \\
\pm 1.4 \mathrm{c}\end{array}$ & 0.64 & 1.4 \\
\hline
\end{tabular}

$\mathrm{Ctrl}=$ control, $\mathrm{WSQ}=$ Endophytic fungi, DW = dry weight. Means of the triplicated data with \pm S.E were separated by Duncan's Multiple Range Test. Means followed by different letters are significantly different at $\mathrm{P}=0.05$ from their respective data points. 
ratio. Rahneshan, et al. [57] observed high $\mathrm{Na} / \mathrm{K}$ and $\mathrm{Na} / \mathrm{Ca}$ ratio in pistachio roots as compared to the leaves after exposing the plants to salt stress. Current results confirmed their findings and recorded an enhanced $\mathrm{Na} / \mathrm{K}$ and $\mathrm{Na} / \mathrm{Ca}$ ratio in salt stressed maize plants. The association of fungal strain (WSQ) with maize plant caused significant reduction in $\mathrm{Na} / \mathrm{K}$ and $\mathrm{Na} / \mathrm{Ca}$ ratio (Table 1). Abd-Allah, et al. [58] reported significant increase in $\mathrm{Ca}, \mathrm{N}, \mathrm{K}$ and $\mathrm{P}$ content while reduction in sodium concentration in AMF associated bean plants under salt stress. The reduced phosphorus and nitrogen level was observed in maize plants after application of $\mathrm{NaCl}$, while inoculation of salt stressed maize plant with WSQ improved the phosphorous and nitrogen levels (Table 1). Mostly crops absorb less phosphorus in the presence of high $\mathrm{NaCl}$ in soil. Gul Jan, et al. [16] stated that the phosphate solubilization might be made by microbes, which is essential for plant development. Wang, et al. [59] worked on rice seedlings and observed negative effects of salt stress on nitrogen ion levels. Moreover, they observed a disturbance in ion-homeostasis of different plant cells, which in turn adversely affected the distribution of ions at cellular, tissue and whole-plant level.

\section{Conclusions}

This investigation focused on the individual and the interactive effect of salt and endophytic fungi $W S Q$ on maize. The results of the study conclude that salt stress caused disturbance in physiology, biochemistry and ionic balance of the maize plants. However, the association of $W S Q$ helped the maize plants to tolerate severe salt stress, which confirms that it can be used as a biofertilizer under saline conditions.

\section{Acknowledgments}

This research was supported by the Basic Science Research Program through the National Research Foundation of Korea (NRF) funded by the Ministry of Education (2017R1D1A1B04035601).

\section{Conflict of Interest}

The authors declare no conflict of interest.

\section{References}

1. KHAN M.A., HAMAYUN M., IQBAL A., KHAN S.A., HUSSAIN A., ASAF S., KHAN A.L., YUN B.-W., LEE I.-J. Gibberellin application ameliorates the adverse impact of short-term flooding on Glycine max L. Biochemical Journal. 475 (18), 2893, 2018.

2. ISMAIL MUHAMMAD H., HUSSAIN A., IQBAL A., KHAN S.A., KHAN M.A., LEE I.-J. An Endophytic
Fungus Gliocladium cibotii Regulates Metabolic and Antioxidant System of Glycine $\max$ and Helianthus annuus under Heat Stress. Polish Journal of Environmental Studies. 30, 1, 2021.

3. RAID A., HUMAIRA G., MUHAMMAD H., MAMOONA R., AMJAD I., MOHIB S., ANWAR H., HAMIDA B., IN-JUNG L. Aspergillus awamori ameliorates the physicochemical characteristics and mineral profile of mung bean under salt stress. Chemical and Biological Technologies in Agricutlure. 8, 1, 2021.

4. QADIR M., HUSSAIN A., HAMAYUN M., SHAH M., IQBAL A., MURAD W. Phytohormones producing rhizobacterium alleviates chromium toxicity in Helianthus annuus L. by reducing chromate uptake and strengthening antioxidant system. Chemosphere. 127386, 2020.

5. BIBI S., HUSSAIN A., HAMAYUN M., RAHMAN H., IQBAL A., SHAH M., IRSHAD M., QASIM M., ISLAM B. Bioremediation of hexavalent chromium by endophytic fungi; safe and improved production of Lactuca sativa L. Chemosphere. 211, 653, 2018.

6. IKRAM M., ALI N., JAN G., JAN F. G., RAHMAN I. U., IQBAL A., HAMAYUN M. IAA producing fungal endophyte Penicillium roqueforti Thom., enhances stress tolerance and nutrients uptake in wheat plants grown on heavy metal contaminated soils. PloS One. 13 (11), e0208150, 2018.

7. DOMÉNECH-CARBÓ A., CERVELLÓ-BULLS P., GONZÁLEZ J.M., SORIANO P., ESTRELLES E., MONTOYA N. Electrochemical monitoring of ROS influence on seedlings and germination response to salinity stress of three species of the tribe Inuleae. RSC advances. 9 (31), 17856, 2019.

8. JAN F.G., HAMAYUN M., HUSSAIN A., JAN G., IQBAL A., KHAN A., LEE I.-J. An endophytic isolate of the fungus Yarrowia lipolytica produces metabolites that ameliorate the negative impact of salt stress on the physiology of maize. BMC Microbiology. 19 (1), 1, 2019.

9. KHUSHDIL F., JAN F.G., JAN G., HAMAYUN M., IQBAL A., HUSSAIN A., BIBI N. Salt stress alleviation in Pennisetum glaucum through secondary metabolites modulation by Aspergillus terreus. Plant Physiology and Biochemistry. 144, 127, 2019.

10. MUHAMMAD I., NIAZ A., GUL J., AMJAD I., MUHAMMAD H., FARZANA G.J., ANWAR H., IN-JUNG L. Trichoderma reesei improved the nutrition status of wheat crop under salt stress. Journal of Plant Interactions. 14, 590, 2019.

11. NUSRAT B., GUL J., FARZANA G.J., MUHAMMAD H., AMJAD I., ANWAR H., HAZIR R., ABDUL T., FAIZA $\mathrm{K}$. Cochliobolus $s p$. acts as a biochemical modulator to alleviate salinity stress in okra plants. Plant Physiology and Biochemistry. 139, 459, 2019.

12. AHMED I., UR RAHMAN M. H., AHMED S., HUSSAIN J., ULLAH A., JUDGE J. Assessing the impact of climate variability on maize using simulation modeling under semi-arid environment of Punjab, Pakistan. Environmental Science and Pollution Research. 25 (28), 28413, 2018.

13. DOWSWELL C. Maize in the third world, CRC Press: Boca Raton, 2019.

14. KUMAR D., JHARIYA A.N. Nutritional, medicinal and economical importance of corn: A mini review. Res J Pharm Sci. 2319, 555X, 2013.

15. NI S., ZHAO W., ZHANG Y., GASMALLA M.A., YANG R. Efficient and eco-friendly extraction of corn germ oil using aqueous ethanol solution assisted by steam explosion. Journal of food science and technology. 53 (4), 
2108, 2016.

16. GUL JAN F., HAMAYUN M., HUSSAIN A., IQBAL A., JAN G., KHAN S.A., KHAN H., LEE I.-J. A promising growth promoting Meyerozyma caribbica from Solanum xanthocarpum alleviated stress in maize plants. Bioscience Reports. 39, 1, 2019.

17. DE FELÍCIO R., PAVÃO G.B., DE OLIVEIRA A.L.L., ERBERT C., CONTI R., PUPO M.T., FURTADO N.A., FERREIRA E.G., COSTA-LOTUFO L.V., YOUNG M.C.M. Antibacterial, antifungal and cytotoxic activities exhibited by endophytic fungi from the Brazilian marine red alga Bostrychia tenella (Ceramiales). Revista Brasileira de Farmacognosia. 25 (6), 641, 2015.

18. HAMAYUN M., HUSSAIN A., KHAN S.A., KIM H.-Y., KHAN A.L., WAQAS M., IRSHAD M., IQBAL A., REHMAN G., JAN S. Gibberellins producing endophytic fungus Porostereum spadiceum AGH786 rescues growth of salt affected soybean. Frontiers in Microbiology. 8, 686, 2017.

19. ISMAIL, ANWAR H., MEHMOOD A., QADIR M., HUSNA, IQBAL A., HAMAYUN M., KHAN N. Thermal stress alleviating potential of endophytic fungus Rhizopus oryzae inoculated to sunflower (Helianthus annuus L.) And soybean (Glycine max L.). Pakistan Journal of Botany. $\mathbf{5 2}, 1,2020$.

20. ISMAIL, HAMAYUN M., ANWAR H., SUMERA AFZAL K., AMJAD I., IN-JUNG L. An endophytic fungus Aspergillus violaceofuscus can be used as heat stress adaptive tool for Glycine max L. and Helianthus annuus L. Journal of Applied Botany and Food Quality. 93, 112, 2020.

21. RAMPADARATH S., PUCHOOA D., JEEWON R., BANDHOA K. Diversity, seasonal variation and antibacterial activity of endophytic fungi associated with the genus Jatropha in Mauritius. J. Biotechnol. Biomater. 8 (280), 2, 2018

22. MACLACHLAN S., ZALIK S. Plastid structure, chlorophyll concentration, and free amino acid composition of a chlorophyll mutant of barley. Canadian Journal of Botany. 41 (7), 1053, 1963.

23. YEMM E., WILLIS A. The estimation of carbohydrates in plant extracts by anthrone. Biochemical journal. 57 (3), $508,1954$.

24. BRADFORD M.M. A rapid and sensitive method for the quantitation of microgram quantities of protein utilizing the principle of protein-dye binding. Analytical biochemistry. 72 (1-2), 248, 1976.

25. VAN HANDEL E. Rapid determination of total lipids in mosquitoes. J Am Mosq Control Assoc. 1 (3), 302, 1985.

26. BATES L.S., WALDREN R.P., TEARE I. Rapid determination of free proline for water-stress studies. Plant and soil. 39 (1), 205, 1973.

27. EL FAR M., TAIE H.A. Antioxidant activities, total anthocyanins, phenolics and flavonoids contents of some sweetpotato genotypes under stress of different concentrations of sucrose and sorbitol. Australian Journal of Basic and Applied Sciences. 3 (4), 3609, 2009.

28. HEATH R.L., PACKER L. Photoperoxidation in isolated chloroplasts: I. Kinetics and stoichiometry of fatty acid peroxidation. Archives of biochemistry and biophysics. 125 (1), 189, 1968.

29. CHANDLEE J., SCANDALIOS J. Analysis of variants affecting the catalase developmental program in maize scutellum. Theoretical and applied genetics. 69 (1), 71, 1984

30. ASADA K. Production and scavenging of active oxygen in photosynthesis. Photoinhibition. 227, 1987.

31. BENIZRI E., COURTADE A., PICARD C., GUCKERT A. Role of maize root exudates in the production of auxins by Pseudomonas fluorescens M. 3.1. Soil Biology and Biochemistry. 30 (10-11), 1481, 1998.

32. HASHEM A., ABD_ALLAH E.F., ALQARAWI A.A., AL-HUQAIL A.A., WIRTH S., EGAMBERDIEVA D. The interaction between arbuscular mycorrhizal fungi and endophytic bacteria enhances plant growth of Acacia gerrardii under salt stress. Frontiers in microbiology. 7, 1089, 2016

33. KANG S.-M., HAMAYUN M., KHAN M. A., IQBAL A. LEE I.-J. Bacillus subtilis JW1 enhances plant growth and nutrient uptake of Chinese cabbage through gibberellins secretion. Journal of Applied Botany and Food Quality. 92, 172, 2019.

34. MAHMUD K., MEDLYN B.E., DUURSMA R.A., CAMPANY C., DE KAUWE M.G. Inferring the effects of sink strength on plant carbon balance processes from experimental measurements. Biogeosciences. 4003, 2018.

35. SEHRAWAT N., YADAV M., BHAT K.V., SAIRAM R.K., JAIWAL P.K. Effect of salinity stress on mungbean (Vigna radiata (L.) Wilczek) during consecutive summer and spring seasons. Journal of Agricultural Sciences, Belgrade. 60 (1), 23, 2015.

36. ISMAIL, HAMAYUN M., HUSSAIN A., AFZAL KHAN S., IQBAL A., LEE I.-J. Aspergillus flavus promoted the growth of soybean and sunflower seedlings at elevated temperature. BioMed Research International. 2019, 1, 2019.

37. AZAD K., KAMINSKYJ S. A fungal endophyte strategy for mitigating the effect of salt and drought stress on plant growth. Symbiosis. 68 (1-3), 73, 2016.

38. ISMAIL, HAMAYUN M., HUSSAIN A., IQBAL A., KHAN S.A., LEE I.-J. Endophytic fungus Aspergillus japonicus mediates host plant growth under normal and heat stress conditions. BioMed Research International. 2018, 2018.

39. OUHADDACH M., ELYACOUBI H., DOUAIK A., ROCHDI A. Morpho-physiological and biochemical responses to salt stress in wheat (Triticum aestivum L.) at the heading stage. Journal of Materials and Environmental Sciences. 9 (6), 1899, 2018.

40. FARHAT N., ELKHOUNI A., ZORRIG W., SMAOUI A., ABDELLY C., RABHI M. Effects of magnesium deficiency on photosynthesis and carbohydrate partitioning. Acta physiologiae plantarum. 38 (6), 145, 2016.

41. BAGHERI A.A., SAADATMAND S., NIKNAM V., NEJADSATARI T., BABAEIZAD V. Effect of endophytic fungus, Piriformospora indica, on growth and activity of antioxidant enzymes of rice (Oryza sativa L.) under salinity stress. International Journal of Advanced Biological and Biomedical Research. 1 (11), 1337, 2013.

42. ISMAIL, HAMAYUN M., HUSSAIN A., AFZAL KHAN S., IQBAL A., LEE I.-J. Aspergillus niger boosted heat stress tolerance in sunflower and soybean via regulating their metabolic and antioxidant system. Journal of Plant Interactions. 15, 223, 2020.

43. SINGH A. The physiology of salt tolerance in four genotypes of chickpea during germination. 2018.

44. ABD-ALLAH E.F., ALQARAWI A.A., HASHEM A., RADHAKRISHNAN R., AL-HUQAIL A.A., AL-OTIBI F.O.N., MALIK J.A., ALHARBI R.I., EGAMBERDIEVA D. Endophytic bacterium Bacillus subtilis (BERA 71) improves salt tolerance in chickpea plants by regulating the plant defense mechanisms. Journal of Pant Interactions. 13 


\section{(1), 37, 2018}

45. CHRISTGEN S.L., BECKER D.F. Role of proline in pathogen and host interactions. Antioxidants and Redox Signaling. 30 (4), 683, 2019.

46. VASS I., UR REHMAN A. The activity of proline as singlet oxygen and superoxide scavenger. Free Radical Biology and Medicine. 120, S75, 2018.

47. AGAMI R., MEDANI R., ABD EL-MOLA I., TAHA R. Exogenous application with plant growth promoting rhizobacteria (PGPR) or proline induces stress tolerance in basil plants (Ocimum basilicum L.) exposed to water stress. Int J Environ Agri Res. 2 (5), 78, 2016.

48. GUAN C., CUI X., LIU H.-Y., LI X., LI M.-Q., ZHANG Y.-W. Proline biosynthesis enzyme genes confer salt Tolerance to switchgrass (Panicum virgatum L.) in cooperation with polyamines metabolism. Frontiers in Plant Science. 11, 46, 2020.

49. ZOHRA E., YOUSSEF M., HASSAN E., KHALID A. Effect of salicylic acid and salt stress on the growth and some biochemical parameters of Mentha suaveolens. Int $\mathbf{J}$ Sci Eng Res. 7, 54, 2016.

50. YANG M.-Z., MA M.-D., YUAN M.-Q., HUANG Z.-Y., YANG W.-X., ZHANG H.-B., HUANG L.-H., REN A.-Y., SHAN H. Fungal endophytes as a metabolic fine-tuning regulator for wine grape. PloS one. 11 (9), e0163186, 2016.

51. OZGUR R., UZILDAY B., SEKMEN A. H., TURKAN I. Reactive oxygen species regulation and antioxidant defence in halophytes. Functional Plant Biology. 40 (9), 832, 2013.

52. GIL L., PINYA S., TEJADA S., CAPÓ X., SUREDA A. Antioxidant Defenses in Wild Growing Halophyte Crithmum maritimum from Inland and Coastline Populations. Chemistry \& biodiversity. 16 (1), e1800448, 2019.

53. NANDI A., YAN L.-J., JANA C.K., DAS N. Role of catalase in oxidative stress-and age-associated degenerative diseases. Oxidative medicine and cellular longevity. 2019, 2019.

54. HASANUZZAMAN M., BHUYAN M., ZULFIQAR F., RAZA A., MOHSIN S.M., MAHMUD J.A., FUJITA M., FOTOPOULOS V. Reactive oxygen species and antioxidant defense in plants under abiotic stress: revisiting the crucial role of a universal defense regulator. Antioxidants. 9 (8), 681, 2020.

55. SAXENA S.C., SALVI P., KAMBLE N.U., JOSHI P.K., MAJEE M., ARORA S. Ectopic overexpression of cytosolic ascorbate peroxidase gene (Apx1) improves salinity stress tolerance in Brassica juncea by strengthening antioxidative defense mechanism. Acta Physiologiae Plantarum. 42 (4), $1,2020$.

56. BILAL L., ASAF S., HAMAYUN M., GUL H., IQBAL A., ULLAH I., LEE I.-J., HUSSAIN A. Plant growth promoting endophytic fungi Asprgillus fumigatus TS1 and Fusarium proliferatum BRL1 produce gibberellins and regulates plant endogenous hormones. Symbiosis. 76 (2), 117, 2018.

57. RAHNESHAN Z., NASIBI F., MOGHADAM A.A. Effects of salinity stress on some growth, physiological, biochemical parameters and nutrients in two pistachio (Pistacia vera L.) rootstocks. Journal of Plant Interactions. 13 (1), 73, 2018.

58. ABD-ALLAH E.F., HASHEM A., ALQARAWI A.A., BAHKALI A.H., ALWHIBI M.S. Enhancing growth performance and systemic acquired resistance of medicinal plant Sesbania sesban (L.) Merr using arbuscular mycorrhizal fungi under salt stress. Saudi journal of biological sciences. 22 (3), 274, 2015.

59. WANG H., WU Z., ZHOU Y., HAN J., SHI D. Effects of salt stress on ion balance and nitrogen metabolism in rice. Plant, Soil and Environment. 58 (2), 62, 2012. 